\title{
Unbalanced Scales of Global Capitalism: Analyzing Temporary Foreign Worker Programs in Canada
}

\section{Emma Callon}

University of Guelph

This article analyzes several characteristics of two of Canada's Temporary Foreign Worker Programs (TFWPs): The Seasonal Agricultural Worker Program (SAWP) and the Live-in Caregiver Program (LCP). First, I consider the social and economic contexts in which these programs have emerged. Second, I discuss how these programs maintain racial and gendered hierarchies. Third, I problematize the relationship TFWPs have with citizenship status, as well as critique TFWPs as a long-term solution to Canadian labour shortages. Last, I discuss the potential benefits of these TFWPs and suggest alternatives and potential improvements to the programs. Using a Marxist framework, this analysis situates Canada's TFWPs within the broader political economy and argues that global capitalism and the state interact to serve the people and economies of the Global North at the expense of migrant workers from the Global South.

Keywords: Marxism; Temporary foreign worker programs; Canadian policy; Migrant workers

Cet article examine deux programmes des travailleurs étrangers temporaires (PTET) du Canada: le Programme des travailleurs agricoles saisonniers (PTAS) et le Programme concernant les aides familiaux résidants (PAFR). Cet essai examine plusieurs aspects des PTET. Premièrement, je tiens compte du contexte social et économique dans lequel ces programmes sont apparus. Deuxièmement, j'explique comment ces programmes maintiennent une hiérarchie basée sur la race et le sexe. Troisièmement, je pose le problème des relations entre les PTET et le statut de citoyen, et je formule également une critique du PTET comme solution à long terme à la pénurie de main-d'œuvre canadienne. Enfin, je discute des avantages potentiels de ces PTET et propose des solutions de rechange et des façons d'améliorer les programmes. À l'aide d'un cadre d'analyse marxiste, les PTET du Canada sont évalués globalement dans le contexte de l'économie politique et il est proposé que le capitalisme mondial et l'État interagissent au service des citoyens et des économies de l'hémisphère nord, au détriment des travailleurs migrants en provenance de l'hémisphère sud.

Mots-clés: Marxisme; programmes temporaires de travailleurs étrangers; la politique canadienne; Travailleurs migrants

\section{Introduction}

This article examines two of Canada's Temporary Foreign Worker Programs (TFWPs): The Seasonal Agricultural Worker Program (SAWP) and the Live-in Caregiver Program (LCP). The purpose of this analysis is to situate Canada's TFWPs within the broader political economy. The research questions this analysis will address are as follows: What is the social and economic context in which these TFWPs have emerged? In what ways are these TFWPs exploitative? What is the relationship between these TFWPs and citizenship status? Lastly, what are the potential benefits of 
both the SAWP and the LCP? As well, I will make recommendations for ways to improve these two TFWPs in Canada. More specifically, this article investigates how global capitalism and the state interact to serve the people and economies of the Global North at the expense of migrant workers from the Global South. The reason for exploring the SAWP and the LCP is to compare and contrast the various dimensions of two fundamentally similar programs that both exist for the purpose of filling a certain type of labour shortage but that function in different realms of the Canadian labour market. In order to address the above research questions, data was collected from secondary sources, including peer-reviewed articles, as well as from primary sources, such as government documents. A Marxist framework, which understands exploitation to be a necessary part of the functioning capitalist system, is used to guide this analysis and interpret the data that has been collected.

Sharma (2012) argues the Canadian state uses immigration policy to reaffirm a global hierarchy based on race, class, and gender. The state uses different types of immigration status such as "temporary worker," "permanent resident," or "citizen" to categorize migrants and label them as various types of marginal. These levels of differentiation are intimately tied to a perceived level of worth, as a temporary worker has fewer rights than a citizen. For instance, unlike citizens, even though temporary foreign workers contribute to the Canadian tax system, they cannot claim unemployment insurance or access welfare assistance. Moreover, temporary foreign workers are tied to their employers, which means their immigration status is tied to their employer (Sharma, 2012, p. 36). This gives workers little freedom to move geographically, bargain, or express dissent, and gives employers the power to reproduce state policy and control in the workplace and home. What this means in Marxist theory is the capitalist is powerful and the workers' labour is exploited. Thus, according to Sharma (2012) "'temporary foreign workers' are a creation of the Canadian state...[they] exist within a state bureaucratic classification scheme designed to hold people in a particular relationship of exploitation and social/political subordination" (p. 35).

Migration for temporary employment purposes has risen in recent years and is now a global trend (Depatie-Pelletier \& Khan, 2011, p. 27; Hennebry \& Preibisch, 2010, p. 20). There are now more temporary foreign workers than traditional entry foreign workers in Canada (Depatie-Pelletier $\&$ Khan, 2011, p. 4). Since the 1970's the majority of people migrating legally to Canada have come through TFWPs (Sharma, 2012, p. 32). In 2004 for example, nearly 80\% of migrants came to Canada as temporary migrant workers with the remaining approximate $20 \%$ being afforded permanent residency (Sharma, 2012, p. 32). This is a significant gap between those who are deemed temporary workers and those who are deemed residents on arrival. According to Statistics Canada, the number of temporary foreign workers coming to Canada "now exceeds 100,000 per year, with some 193,061 individuals entering... in 2008" (Hennebry \& Preibisch 22). The SAWP alone employs 27,000 people from Mexico and the Caribbean yearly (Hennebry \& Preibisch, 2010, p. 20). What this tells us is that people migrating to Canada under a temporary work agreement is the new norm. Thus, its implications on both migrants and Canada's labour market and economy must be explored.

What follows is a brief description of the SAWP and the LCP. The SAWP has existed for over forty years and hires more and more migrants from Mexico and the Caribbean (Anguilla, Antigua and Barbuda, Barbados, Dominica, Grenada, Jamaica, Montserrat, St. Kitts-Nevis, St. Lucia, St. Vincent and the Grenadines, and Trinidad and Tobago) each year (Hennebry \& Preibisch, 2010, p. 35; Government of Canada, 2014a). Migrants are hired for a maximum of eight months and work with the following commodities: apiary products, fruits, vegetables, flowers, Christmas trees, sod, tobacco, bovine, dairy, duck, horse, mink, poultry, sheep, and swine. The program is 
open to both men and women eighteen years of age and older (Government of Canada, 2014b).

The LCP as it is now was created in 1992 as a "special federal immigration program whose objective is to bring qualified temporary workers to Canada to provide care for children, the elderly, or persons with disabilities in private family households" (Bakan \& Stasiulis 2012, p. 204). What preceded the LCP was the Foreign Domestic Movement Program (FDM), which existed from 1981 to 1992 and was focused only on filling a need for childcare (Bourgeault et al., 2010, p. 85). The number of people entering Canada through the LCP is steadily increasing from about 2,000 in 1996 to 6,717 in 2007 , with the total number of participants being over 30,000 in 2007 and over $80 \%$ coming from the Philippines (Bourgeault et al., 2010, p. 86).

Both of the SAWP and LCP are only increasing in size and popularity and require low skill labour. However, the LCP requires experience, education, and language proficiency, whereas these are not requirements of the SAWP. Another difference in these programs is that, unlike the SAWP, the LCP is advertised as a pathway to citizenship, as participants can apply for permanent residency after two years in the program (Bakan \& Stasiulis 2012, p. 204; Government of Canada, 2014b). Prior to 2014 the only requirement for participants in the LCP to qualify for permanent residency was that they complete two years in the program. However, in 2014 the Government of Canada added requirements beyond participating in the LCP for two years. Specifically, in addition to participating in the LCP for two years, live-in caregivers now must have at least one year of postsecondary study in Canada, or in a country given equivalency in Canada (Black 2014). As well, participants in the LCP who wish to apply for permanent residency now must pass a Level 5 language test in either French or English (Black 2014). An additional change to the LCP is that if participants fail to obtain permanent resident status they will be sent home after four years, adding more uncertainty and precariousness for participants (Black 2014). One improvement to the LCP in recent years is the removal of the live-in requirement. Traditionally, both the SAWP and LCP required participants to live with their employers or on their employer's property, but after live-in caregivers contested violations to their contracts and campaigned for policy changes, the live-in requirement was removed from the LCP, although it remains in the SAWP (Black 2014; Tungohan, Banerjee, Chu, Cleto, de Leon, Garcia, Kelly, Luciano, Palmaria \& Sorio, 2015, p. 88). Additionally, the SAWP is advertised to both men and women whereas the LCP is not explicit about gender requirements, but implies a preference for women.

\section{The Emergence of TFWPs}

Our social, political, and economic world has changed over the last half century. During this period we have seen global and economic restructuring in the form of global capitalism and neoliberalism. These transformations in the political economy have affected people around the world and are especially relevant to this examination of TFWPs in Canada.

Kofman (2004) cites "economic and social transformations brought about by globalizing processes" as a reason for recent immigration trends being highly stratified immigration categories based on class, gender, and race or nationality such as with the TFWPs (p. 644). The author suggests globalization produces hierarchical systems of inclusion and exclusion through mobility -or who is accepted into Canada and on what terms. This hierarchy can be seen in Canada's TFWPs, as "the lesser skilled... are either allowed to enter with lesser rights, or prevented from entering legally" (Kofman, 2004, p. 665). Bakan and Stasiulis (1994) verify Kofman's argument and hold global capitalism accountable for the recent influx of global migration and the stratification by which it is characterized. These authors also mention "distorted development among third-world labour 
exporting regions" as a factor contributing to migration (p. 8). These may be failed development projects, corrupt governance, poor economies, or extreme wealth inequality. Bakan and Stasiulis (1994) further note the increase in precarious work around the world, involving jobs that are lowwage and "unprotected" as a reason for intensified immigration and labour stratification (p. 9). Our capitalist system is based on class divisions -those who sell their labour and those who control labour. However, the authors suggest that with global capitalism and more precarious low skill work our "capitalist labour force has become further segmented," not only by class, but "by gender, race, and ethnicity" and also citizenship status, which governs workers' rights, freedoms, and labour legislation protection (Bakan \& Stasiulis, 1994, p. 9).

Global capitalism involves the creation of a transnational capitalist class. What this means is that the bases of capitalism, which are modes of production and our financial system, are increasingly integrated and global. As well, global capitalism is characterized by an increase of multinational and transnational companies, and states becoming more global and secondary to markets. Lastly, global capitalism is characterized not only by inequality within nations but across borders as well, with certain nations selling their goods and labour for capitalist consumption. Global capitalism started in the late 1970's and early 1980's with "the weakening and transformation of welfare states in the capitalist West, the collapse...of...the communist East, and the undermining of developmental states in what had been called the Third World" (Postone, 2007, p. 7). More broadly, these transformations in the political economy were due to long-term economic downturn and a global integration of our social, political, and cultural lives (Postone, 2007, p. 7). It has been suggested that the cause of the economic downturn of the $20^{\text {th }}$ century is due to economic competition by Germany and Japan after World War II, as these countries began to produce more goods. Consequently, rather than bow down to competitive advantage the US continued manufacturing, which led to overproduction, falling profits, and increased competition (Postone, 2007 , p. 10). In summation, global capitalism is marked by global competition, and it is because of these new competitive pressures that states have had "to engage in a number of strategies to protect their own position within the globalized political economy" such as borrowing cheap foreign labour (Hennebry \& Preibisch, 2010, p. 21).

It is difficult to talk about global capitalism without discussing neoliberalism. Neoliberalism emerged in the mid 1980's and early 1990's through "neoliberal regime shifts and neoliberal policy adjustments" (Jessop, 2007, p. 71). Neoliberalism is essentially a set of "economic policies based on liberalization, deregulation, privatization, market proxies in the residual public sector, internationalization, and reduced direct taxation - a set of policies that are intended to alter the balance of forces in favour of capital" (Jessop, 2007, p. 70). Thus, clearly with neoliberalism there is an intended set of winners and they are the already powerful capitalist class. This makes the losers of neoliberalism those who sell their services and labour to the capitalists -workers from the Global South.

What has been described above is the context in which TFWPs such as the SAWP and LCP emerged. Within the neoliberal global capitalist context exists a real or perceived labour shortage in Canada. This 'shortage' of low skill low wage work is what TFWPs attempt to fill. DepatiePelletier and Khan (2011) write: "Globalization, and the push to fulfill the neoliberal economic and political agenda, have moved Canada away from its previous commitment of nation-building into the fixated search for more flexible and disposable low skilled migrants to serve as economic units to fill industrial production labor shortages dictated, in part, by global trends towards lower labour costs and degradation of work conditions" (p. 4). Whether or not this shortage is real or perceived has been debated. It is argued that the shortage exists because of "a booming economy, an aging 
workforce, and an increasingly educated population unwilling to take low skilled jobs" (DepatiePelletier \& Khan, 2011, p. 29). Thus, calling it a shortage may be misleading, as the jobs temporary foreign workers take are the ones rejected by Canadians. In other words, there exists a shortage of a certain kind of worker -ones who are cheap and willing to work for low wages, who are politically repressed, and who are willing to do dirty, dangerous, and difficult work - what Bakan and Stasiulis (2012) call "free" wage labourers (p. 204; Depatie-Pelletier \& Khan, 2011, p. 48). Highlighting the role of neoliberalism in the rise of TFWPs, it has been argued a "care deficit" exists as a result of reduced spending on social care programs and healthcare restructuring (Torres, 2012, p. 228). This restructuring, combined with an increase in dual-earner families, creates a need for caregivers that could otherwise be supplemented with social programs, and has shaped the LCP.

It is clear a labour shortage exists; whether it is because there are too few Canadians to fill this type of low skill work or because Canadians do not want to do this type of work is less important. What is important is that temporary foreign workers are considered to be the long-term solution to this labour shortage, rather than rehabilitating the Canadian welfare state. Immigration in the form of temporary foreign workers is part of the Canadian government's "comprehensive labour market strategy" (Depatie-Pelletier \& Khan, 2011, p. 29). Depatie-Pelletier and Khan (2011) suggest that because more and more temporary foreign workers are coming to Canada every year the "labour market needs they are filling are not temporary, but instead long-term, permanent, if not increasing" (p. 14). Moreover, it is not only the Canadian government and Canadian employer demands that pull migrants into temporary work; it is also the governments of the labour exporting countries that encourage labour migration. For instance, the Philippine government encourages Filipinos to enter the LCP due to remittances Canadian work supplies the country and the fact that it absolves the Philippine government from the responsibility of addressing the country's lackluster economy (Torres, 2012, p. 232).

\section{TFWPs and Exploitation}

Both the SAWP and LCP have exploitative elements, and at the very least disadvantage the foreign workers they employ. The most obvious ways these two programs are exploitative are that the employees are racialized, the work is gendered, working conditions are poor and constraining, and lastly these programs tie citizenship status to employers.

\section{Race}

There is a narrative that exists in Canada and that is that foreign workers are satisfied with the work rejected by Canadians and that they are lucky to work in Canada regardless of their pay or working conditions (Sharma, 2012, p. 38). This discourse subordinates and differentiates foreign workers from Canadians in the labour market and facilitates their racialization. For instance, a racial hierarchy persists in the LCP. According to Bakan and Stasiulis (2012) darker skinned women "suffer from the most demeaning of racial stereotypes" and "are assigned the least desirable and dirtiest forms of domestic labour," unlike lighter skilled women who are assigned preferential work (p. 216). Not to mention, most women employed through the LCP are from the Philippines, which shows a clear racial preference toward Filipinos (Torres, 2012, p. 227). This form of racial stratification is rooted in colonialism and the institution of slavery. For instance, during $18^{\text {th }}$ and $19^{\text {th }}$ Century slavery in the US, darker-skinned people were relegated to work in the fields, while lighter-skinned people who might have been the offspring of slave-owners often worked in the 
house, which involved preferential domestic labour. Similar trends can be seen in the LCP, as Filipinas are often light-skinned and are less 'othered' than dark-skinned migrants from other countries. It can be argued that because Filipinas are light-skinned they are more 'like' white Canadians. Therefore, the Canadian state and Canadian families inadvertently prefer Filipinas and welcome them more than darker-skinned migrants. Thus, Filipino women are the majority participants in the LCP and are preferred to undertake care work because they are perceived as 'safe' to interact with Canadian children and be out in Canadian neighourhoods. The SAWP also very clearly racializes the workers that come into the program. As was mentioned above, the program only employs people from Mexico and the Caribbean. Moreover, Canadian employers are allowed to select workers based on their nationality or race. This encourages employers to essentialize people based on their skin colour or nationality. This process of essentializing seasonal migrant agriculture workers based on their race also has roots in the US slave trade and the social construction of race. For instance, during the slave trade certain physical attributes and characteristics, such as size or place of origin, were considered desirable for certain types of labour and slaves were bought and sold on the basis of assumed characteristics associated with certain traits. Consequently, Canadian employers have been led to deem certain groups hard working and others as potentially lazy, which perpetuates certain racial stereotypes. This racial stratification is problematic because it creates unhealthy competition between workers, encourages workers to racialize each other, and prevents the possibility of worker solidarity. For instance, if a Mexican worker is perceived to be lazy, a Jamaican worker may define himself by what the Mexican is not, and try to present himself in such a way that associates being Jamaican with being hardworking, which ultimately divides workers.

Racializing workers also creates competition between labour exporting countries founded on the degradation of another country's migrant workers. Mexico and Jamaica for example become competitive and try to provide 'good' workers and meet Canadian employer expectations. Thus, allowing employers to "divide the workforce on the basis of citizenship, language, gender, and nationality" is racist and disadvantageous to workers. This is because it reduces workers to their assumed racialized traits rather than recognizing their potential skills and experiences. As well, the process creates a lack of solidarity between workers and between workers and their exporting country governments, as the workers are basically commodities (Hennebry \& Preibisch, 2010, p. 25).

\section{Gender}

Both the SAWP and LCP are highly gendered. Moreover, the way these programs are gendered reaffirms traditional ideas about men and women. Specifically, even though the SAWP is open to both men and women, an overwhelming percentage (97\%) of the participants are men (DepatiePelletier \& Khan, 2011, p. 67). Furthermore, women are overrepresented in the LCP and service and domestic work in general (Sharma, 2012, p. 34). What this tells us about gender is that men are expected to sustain their families through hard physical labour outside the home that directly contributes to the economy, as they do in the SAWP, and women are required to reproduce family life, as they do in the LCP (Parreñas, 2001, p. 63). Within capitalism, the family is understood to be the basic social unit and a clear gendered division of labour exists as a way to sustain the capitalist system. Specifically, within capitalism men are traditionally visible as wage earners and occupy public space. In contrast, women are visible as mothers and occupy private spaces, such as in the home (Crompton, 1999, p. 17). This gendered division of labour is the result of gendered 
essentialisms that perceive women as innately maternal and caregiving. Thus, because the LCP primarily hires women the program perpetuates a gendered division of labour where women are valued for certain assumed characteristics or traits. As an implication, Filipino women are essentialized and relegated to the home to provide domestic labour and care to Canadian families, reproducing Canadian family life. As well, participants in the LCP are expected to sustain their own families abroad by sending remittances and providing an avenue for their dependents to eventually migrate to Canada.

According to Parreñas (2001) there exists an international division of labour, which is facilitated by the LCP. The author refers to this phenomenon as a "three tier hierarchy of international transfer of caretaking" (Parreñas, 2001, p. 73). What this concept means is that we live in a patriarchal world system where women's work is still perceived to be reproductive work and these beliefs exist across borders. Hence, the LCP frees women from the Global North from domestic work and allows them to enter the workforce with ease and contribute to the Canadian economy. However, the domestic work is simply shifted to another type of woman -women from the Global South. Additionally, this shift leaves children in the Global South in need of care and so even poorer women in the Global South are hired to care for the children of migrants. Thus, domestic work becomes gendered and racialized, as women move "from one distinct patriarchal system to another, bound by class, in transnational capitalism" (Parreñas, 2001, p. 78). The result is that patriarchal systems are not challenged and women are still bound to reproductive labourthe system is just further complicated.

\section{Working Conditions and Control}

Workers participating in both the SAWP and LCP are either required to or tend to live where they work. This can be constraining for workers because they are always 'at work', potentially always on call, forced to work overtime hours, isolated, and have little time off from work. Living at work and with employers also increases the likelihood workers will be abused and that workers will avoid complaining about substandard living conditions. With the SAWP workers must live on the farm on which they work. There are "subjective perceptions of acceptable" housing, as standards are not enforced nor monitored regularly (Hennebry \& Preibisch, 2010, p. 30; Depatie-Pelletier \& Khan, 2011, p. 67). With the LCP, workers often live in the house of the employer, as affordable housing in Canada can be inaccessible (Bakan \& Stasiulis, 2012, p. 209). This is problematic because it leads to workers being over-worked and feeling isolated, as they are alone in the employer's home with the employer. For workers in the LCP, their place of work is also often their home, and thus the home becomes divided by employee and employer, by class, race, and by gender, which reproduces and symbolizes global inequalities (Bakan \& Stasiulis, 2012, p. 209).

Temporary foreign workers are bound to their employer by the terms of their work programs, immigration status, and housing accommodations (Sharma, 2012, p. 36). This is highly restrictive and constraining. Because workers are tied to their employers in the SAWP and LCP, they are unable to move freely in the Canadian labour market and are therefore unable to bargain. Workers in the LCP often have restricted mobility, as in they may not be able to leave the house or do so only at certain times, and have no accessible formal paths to complain (Torres, 2012, p. 236). There are also instances of forced savings in the SAWP and workers are forbidden to unionize (Hennebry \& Preibisch, 2010, p. 32; Depatie-Pelletier \& Khan, 2011, p. 19). The LCP appears especially isolating as workers have little contact with other participants in the program given that they all live and work in separate houses. Moreover, it is not feasible to bring family as Canadian 
rent prices are high and employers usually only have one room in their home for the caregiver (Bakan \& Stasiulis, 2012, p. 205). Additionally, if workers are restricted from leaving the house they are unlikely to access support systems from other caregivers, friends, family, churches, or other important networks. On a psychological level, participants in the LCP may feel isolated as it may become clear they are an important part of maintaining the household, but are not part of the family.

\section{Citizenship Status}

The institutionalized inequalities that have been discussed above, including race, gender, and living conditions, all function to disadvantage workers and heighten their vulnerability (Bakan \& Stasiulis, 2012, p. 203). This is because the state essentially sides with the employers rather than with the workers. In other words, through the SAWP and LCP the Canadian state sanctions racialized, gendered, and unfree employment of temporary foreign workers. These workers become a distinct class of workers in the Canadian labour market -ones who are differentiated and excluded from rights and freedoms afforded to Canadian citizens. This discussion will now turn to how citizenship status is linked with employment to create different and unequal classes of workers in Canada.

According to Depatie-Pelletier and Khan (2011) "temporary workers have a place in the economy but not in the nation" (p. 48). The Canadian state benefits from temporary foreign workers through the workers' contribution to the economy by their filling of undesirable jobs. Furthermore, the state benefits by not having to provide workers with many of the rights and freedoms afforded to Canadian citizens. This is especially true with the SAWP as there is no real path to citizenship for its participants, unlike the LCP.

In both the SAWP and LCP workers are allowed to enter Canada with the agreement that they participate in these programs. Thus, their legal status in Canada is directly related to their employment and employer. This is problematic because if a participant in the SAWP or LCP loses their employment they will automatically lose their right to work in Canada (Depatie-Pelletier \& Khan, 2011, p. 13). These terms do not take into consideration the possibility that a temporary foreign worker in the SAWP or LCP may be dismissed on unfair grounds. There are, however, legal measures a worker can take to complain about an unjust dismissal but the odds of workers going down that path are slim. This is due to a fear of being blacklisted from the TFWP and because legal processes are time consuming and without a permit to work in Canada workers are unable to support themselves while the legal process unfolds. Thus, as a temporary foreign worker "you have rights, but you will certainly lose your status before being able to exercise them" (Depatie-Pelletier \& Khan, 2011, p. 14). Moreover, if a worker is found to be in violation of the terms of their TFWP they may also be considered to be violating Canadian immigration regulations, which can prevent them from accessing Canadian work permits in the future (Depatie-Pelletier \& Khan, 2011, p. 18). The Canadian Labour Congress has called this policy into question, as it "places an unfair and impractical burden on migrant workers" (Depatie-Pelletier \& Khan, 2011, p. 18).

Although both the SAWP and LCP tie workers' citizenship status to their employment, the LCP is advertised as a path to citizenship, unlike the SAWP. With the SAWP low skilled workers are hired for a short period and then expected to return to their home countries. These workers are not encouraged to and have no option to settle in Canada or apply for a permanent resident status (Hennebry \& Preibisch, 2010, p. 32). Typically, "low skilled or unskilled occupations are generally designed to prevent settlement and restrict mobility" (Hennebry \& Preibisch, 2010, p. 20). 
However, the LCP is different. The LCP is framed as an immigration work program. Thus, it is advertised that a participant can apply for permanent residency, albeit with stipulations, after two years of full time work in the program (Bakan \& Stasiulis, 2012, p. 204; Government of Canada, 2014b).

It is curious that workers in the LCP are clearly encouraged to settle in Canada whereas workers in the SAWP are discouraged from settling in the country or applying for residency. The SAWP and LCP are the same in that they employ foreign labour to fill a low skill low wage labour shortage in Canada. However, the programs are different in that participants from the LCP are mostly Filipino women, have language skills in English or French, and have experience and education -usually BA degrees (Torres, 2012, p. 234). Participants in the SAWP are Mexican and Caribbean men with no necessary language skills or educational experience. What this suggests is that even though both types of work in the agriculture and domestic service sector require low skill foreign labour, it is educated Filipino women to which the Canadian state would prefer to afford a space in the nation. It may also be that because participants in the LCP are required to live in the homes of everyday 'middle class' Canadians and are the ones who will interact with Canadians on a more personal and everyday basis, as they are the ones running neighbourhood errands for families, taking kids to the park, and reproducing Canadian family life, it is safer and comfortable to have the least 'foreign' of the foreign people -that being light skinned Filipino women who speak English or French and who have formal education.

To sum up this discussion of citizenship, ideally rights and freedoms should be inherent to all people, not afforded to people based on a person's level of membership to a certain state, nor on the basis of class, gender, race, or country of origin. However, although this is the ideal it may be impractical in the conservative capitalist Canada we live in today. However, improvements can be made. Rights and freedoms need not be divided subjectively based on a person's perceived worth, which in turn creates a new class of migrant whose immigration status is tied to an employer. Because temporary foreign workers are placed in a limbo where they are not residents and have little mobility, temporary workers are forced to be dependent on employers and the state. Thus, these workers are not free, nor able to settle into Canadian society, especially when racial, classed, and gendered inequalities are institutionalized through immigration and work programs.

\section{Discussion}

The Canadian state employing foreign labour is not inherently bad and does not have to be exploitative. In theory, employing foreign labour can be harmonious if a shortage of workers exists in Canada and a shortage of labour opportunities exists in a developing country like the Philippines. As they are today, TFWPs benefit developing countries through the remittances that migrant labourers supply to their families. Torres (2012) says remittances are a "central economic pillar" for many developing countries such as the Philippines (p. 229). However, remittances being central to many economies in the developing world may not be a benefit in the long term. This is because it can absolve governments in developing countries of responsibility to improve their economies and provide quality employment opportunities for people in the country. Thus, remittances may not necessarily contribute to sustainable development (Hennebry \& Preibisch, 2010, p. 33). Additionally, developing countries benefit by having more highly skilled workers potentially return to the country. Furthermore, migrant workers "may benefit from the opportunity to increase productivity and wages" (Hennebry \& Preibisch, 2010, p. 33). As well, TFWPs provide formal channels for migrants to enter Canada, which can curb illegal immigration and human trafficking 
(Hennebry \& Preibisch, 2010, p. 21). Not to mention, TFWPs provide a channel for migrants who do not meet the qualifications of the points system to enter Canada (Bourgeault et al. 2010 p. 84).

In spite of the benefits mentioned above, the problem with TFWPs in Canada are the exploitative factors discussed earlier, which leads to an imbalance in the beneficiaries of TFWPs. Hence, the Canadian state and employers benefit from these programs more than developing countries and significantly more than the migrant workers from those developing countries (Hennebry \& Preibisch, 2010 p. 26). Depatie-Pelletier and Khan (2011) write "although migrant workers benefit from the program, the North has the upper hand in the bilateral agreement" (p. 62). This is because the state gains economic entities, while those economic entities are exploited for their labour. In speaking about the LCP specifically, Bakan and Stasiulis (2012) write that the program "is an instance of state and global accommodation of the needs of families in the Global North through the enforcement of extraordinary conditions for migrant household workers, the vast majority of whom are women from the Global South" (p. 206). Furthermore, the LCP is meant to be "a means to an end," with the end being improved citizenship status and better access to economic opportunities (Bakan \& Stasiulis, 2012, p. 214). However, the end is not guaranteed and live-in caregivers may face difficulty leaving domestic work and significantly improving their economic situations, especially living in a country where people are gendered and racialized on an institutional level and in the labour market. This imbalance of the benefits of TFWPs reflects the fundamental characteristic of neoliberalism, which is to tip the scales of power in favour of capital.

There are many specific elements of TFWPs, such as the SAWP and LCP, that can be improved to balance the benefits of the programs in a more equal way, so that migrant workers are less significantly on the losing end. The following are some of the most essential changes that should be made to the programs. One improvement that can be made in Canada is in immigration policy. There is a need for more channels to permanent migration rather than only through the points system, which favours certain immigrants, and through TFWPs, which are highly stratifying and exploitative (Depatie-Pelletier \& Khan, 2011, p. 39). Another important improvement would be strengthening the supervision and monitoring of living and working conditions (DepatiePelletier \& Khan, 2011, p. 52). As well, the live-in requirement of the SAWP should be an accessible option rather than mandatory, with affordable housing made available. Lastly, temporary foreign workers should be allowed and encouraged to unionize. Regarding the LCP specifically, workers should be allowed and encouraged to meet with other participants in the program on a regular basis. This would likely curb feelings of isolation, lead to less restrictions and controls, and could facilitate unionization, or at least solidarity.

While formal changes to aspects of TFWPs would be crucial to improving migrants' experiences in the programs, the major change that is most difficult but is the most meaningful would be the dismantling of global capitalism and neoliberalism. Our political economy "has prioritized market imperatives over social policy and equity considerations" (Depatie-Pelletier \& Khan, 2011, p. 4). This prioritization has lead to the marginalization of workers from the Global South and inequality within Canada and on a global scale. In addition to a shift in the political economy, a culture of individualism and entitlement, which goes hand-in-hand with capitalism and leads to race and gender inequalities, must also shift. The shift must move away from favouring market competition to promoting social equality and inclusion in Canadian society.

Conclusively, Canada's TFWPs, and the SAWP specifically, are held up as exemplary managed temporary migrant worker programs in the international community (Hennebry \& Preibisch, 2010, p. 23). However, after this analysis, it is clear these programs are not in fact ideal models of immigration work programs as they are largely exploitative, essentializing, restrictive, 
and exclusionary. Moreover, TFWPs are congruent with Marx's understanding of capitalism, which is that exploitation is necessary to the functioning of the capitalist system. More broadly, international exploitation is essential for the functioning of global capitalism. Thus, it is important to ask: Is global capitalism working, and if it is working, for whom is it working?

About the author

Emma Callon received her MA in Sociology and Anthropology at the University of Guelph. She can be reached at emmarcallon@gmail.com

\section{References}

Bakan, A. B. \& Stasiulis, D. (1994). Foreign Domestic Worker Policy in Canada and the Social Boundaries of Modern Citizenship. Science \& Society, 58, 7-33.

Bakan, A. B. \& Stasiulus, D. "The Political Economy of Migrant Live-in Caregivers: A Case of Unfree Labour?", pp. 202-226, in Lenard, P. T. \& Straehle, C. (eds.), Legislated Inequality: Temporary Labour Migration in Canada. Montreal and Kingston: McGillQueens University Press, 2012.

Black, D. 2014. "New rules for federal live-in caregivers program." November 28 The Star. Retrieved March 30, 2016 http://www.thestar.com/news/canada/2014/11/28/new_rules_for_federal_livein_caregiver s_program.html)

Bourgeault, I. L., Rishma, P. \& Atanackovic, J. (2010). Canada's Live-In Caregiver Program: Is it an Answer to the Growing Demand for Elderly Care?. Population Ageing, 3, 83-102.

Crompton, R. (1999). "The Decline of the Male Breadwinner: Explanations and Interpretations." Pp. 1-25 in Restructuring Gender Relations and Employment: the Decline of the Male Breadwinner, edited by R. Crompton. Oxford and New York: Oxford University Press.

Depatie-Pelletier, E. \& Khan, R. S. (2011). Mistreatment of temporary foreign workers in Canada: Overcoming regulatory barriers and realities on the ground. Montréal, Que.: Centre Métropolis du Québec.

Government of Canada. (2014a). Hiring Seasonal Agricultural Workers. Retrieved from http://www.esdc.gc.ca/eng/jobs/foreign_workers/agriculture/seasonal/index.shtml

Government of Canada. (2014b). Hiring Live-in Caregivers and Nannies. Retrieved from http://www.esdc.gc.ca/eng/jobs/foreign workers/caregiver/index.shtml 
Hennebry, J. L., \& Preibisch, K. (2010). A Model for Managed Migration? Re-Examining Best Practices in Canada's Seasonal Agricultural Worker Program. International Migration. 50, $19-40$.

Jessop, R. (2007). "What follows Neo-liberalism? The Deepening Contradictions of US Domination and the Struggle for a New Global Order", pp. 67-88 in Albritton, R.., Jessop, R. \& Westa, R. (eds.), Political Economy and Global Capitalism. UK \& USA: Anthem Press.

Kofman, E., (2004). Gendered Global Migrations. International Feminist Journal of Politics, 6, 643-665.

Parreñas, R. S. (2001). “The International Division of Reproductive Labor,” pp. 61-79, in Parreñas, R. S., Servants of Globalization: Women, Migration, and Domestic Work. Stanford: Stanford University Press.

Postone, M. (2007). "Theorizing the Contemporary World: Robert Brenner, Giovanni Arrighi, David Harvey", pp. 7-24 in Albritton, R., Jessop, R. \& Westa, R. (eds.), Political Economy and Global Capitalism. UK \& USA: Anthem Press.

Sharma, N. (2012) “The 'Difference' that Borders Make: 'Temporary Foreign Workers' and the Social Organization of Unfreedom in Canada", pp. 26-47 in Lenard, P. T. \& Straehle, C. (eds.), Legislated Inequality: Temporary Labour Migration in Canada. Montreal and Kingston: McGill-Queens University Press.

Torres, S., Spitzer, D. L., Hughes, K. D., Oxman-Martinez, J. \& Hanley, J. (2012) “From Temporary Worker to Resident: The LCP and Its Impact through an Intersectional Lens", pp. 227-244 in Lenard, P. T. \& Straehle, C. (eds.), Legislated Inequality: Temporary Labour Migration in Canada. Montreal and Kingston: McGill-Queens University Press.

Tungohan, E., Banerjee, R., Chu, W., Cleto, P., de Leon, C., Garcia, M., Kelly, P., Luciano, M., Palmaria, C., \& Sorio, C. (2015). After the Live-In Caregiver Program: Filipina Caregivers' Experiences of Graduated and Uneven Citizenship. Canadian Ethnic Studies, $47(1), 87-105$. 